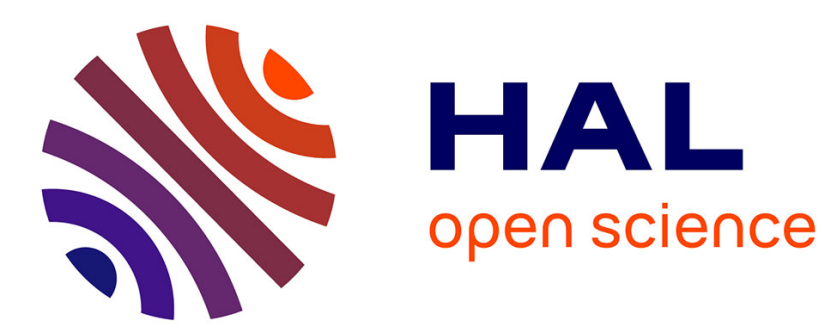

\title{
Survival of Fusarium graminearum, the causal agent of Fusarium head blight. A review
}

Johann Leplat, Hanna Friberg, Muhammad Abid, Christian Steinberg

\section{To cite this version:}

Johann Leplat, Hanna Friberg, Muhammad Abid, Christian Steinberg. Survival of Fusarium graminearum, the causal agent of Fusarium head blight. A review. Agronomy for Sustainable Development, 2012, 33 (1), pp.97-111. 10.1007/s13593-012-0098-5 . hal-01201382

\section{HAL Id: hal-01201382 \\ https://hal.science/hal-01201382}

Submitted on 17 Sep 2015

HAL is a multi-disciplinary open access archive for the deposit and dissemination of scientific research documents, whether they are published or not. The documents may come from teaching and research institutions in France or abroad, or from public or private research centers.
L'archive ouverte pluridisciplinaire HAL, est destinée au dépôt et à la diffusion de documents scientifiques de niveau recherche, publiés ou non, émanant des établissements d'enseignement et de recherche français ou étrangers, des laboratoires publics ou privés. 


\title{
Survival of Fusarium graminearum, the causal agent of Fusarium head blight. A review
}

\author{
Johann Leplat • Hanna Friberg • Muhammad Abid • \\ Christian Steinberg
}

Accepted: 10 May 2012 / Published online: 14 June 2012

(C) INRA and Springer-Verlag, France 2012

\begin{abstract}
Wheat is one of the most cultivated crops worldwide. In 2010, $20 \%$ of wheat and durum wheat were cultivated in Europe, $17 \%$ in China and $9 \%$ in Russia and in North America. Wheat yield can be highly decreased by several factors. In particular Fusarium graminearum Schwabe is a worldwide fungal pest impacting wheat production. F. graminearum is the causal agent of Fusarium head blight, root and stem-base rot of cereals. Losses caused by Fusarium head blight in Northern and Central America from 1998 to 2002 reached $\$ 2.7$ billion. Moreover, F. graminearum produces mycotoxins which affect human and animal health. The threshold of these mycotoxins in foodstuffs is regulated in Europe since 2007. F. graminearum survives for several years saprotrophically in the soil, on
\end{abstract}

\footnotetext{
J. Leplat $\cdot$ M. Abid $\cdot$ C. Steinberg $(\bowtie)$

INRA, UMR1347 Agroécologie,

Interactions Plante-Microorganismes (IPM),

21065 Dijon, France

e-mail: christian.steinberg@dijon.inra.fr

J. Leplat

e-mail: johann.leplat@dijon.inra.fr

M. Abid

e-mail: muhammad.abid@dijon.inra.fr

J. Leplat $\cdot$ M. Abid $\cdot$ C. Steinberg

Université de Bourgogne, UMR1347 Agroécologie,

Interactions Plante-Microorganismes (IPM),

21065 Dijon, France

J. Leplat $\cdot$ M. Abid $\cdot$ C. Steinberg

Agrosup, UMR1347 Agroécologie,

Interactions Plante-Microorganismes (IPM),

21065 Dijon, France

\section{H. Friberg}

Swedish University of Agricultural Sciences (SLU),

Department of Forest Mycology and Pathology,

Box 7026, 75007 Uppsala, Sweden

e-mail: hanna.friberg@slu.se
}

dead organic matter, particularly on crop residues. $F$. graminearum adapts to a wide range of environmental variations, and produces extracellular enzymes allowing feeding on different crop residues. However, F. graminearum competes with other decomposers such as other Fusarium spp. belonging to the same complex of species. Actually, it is not known whether $F$. graminearum mycotoxins give $F$. graminearum a competitive advantage during the saprotrophic period. Anthropogenic factors including preceding crops, tillage system and weed management can alter the development of the soil biota, which in turn can change the saprotrophic development of $F$. graminearum and disease risk. We review the ecological requirements of $F$. graminearum saprotrophic persistence. The major conclusions are: (1) temperature, water, light and $\mathrm{O}_{2}$ are key conditions for $F$. graminearum growth and the development of its sexual reproduction structures on crop residues, although the fungus can resist for a long time under extreme conditions. (2) $F$. graminearum survival is enhanced by high quantities of available crop residues and by rich residues, while sexual reproduction structures occur on poor residues. (3) F. graminearum is a poor competitor over time for residues decomposition. F. graminearum survival can be controlled by the enhancement of the decomposition processes by other organisms. In addition, the development of $F$. graminearum on crop residues can be limited by antagonistic fungi and soil animals growing at the expense of $F$. graminearuminfested residues. (4) Agricultural practices are key factors for the control of $F$. graminearum survival. A suitable crop rotation and an inversive tillage can limit the risk of Fusarium head blight development.

Keywords Crop residues - Ecological requirements · Habitat $\cdot$ Mycotoxins $\cdot$ Preceding crop $\cdot$ Saprotrophic development $\cdot$ Soil microbial ecology $\cdot$ Tillage $\cdot$ Wheat diseases 


\section{Contents}

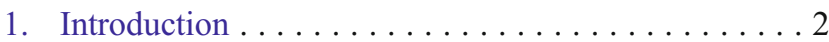

2. Fusarium graminearum .............. 3

2.1 Fusarium diseases on wheat .......... 3

2.2 Saprotrophic growth . . . . . . . . . . . 4

2.3 Environmental factors controlling saprotrophic survival ................. 5

3. Effect of crop residues as $F$. graminearum growth substrates in the soil ..............6

3.1 Effect of crop residues quantities . . . . . . . . . 6

3.2 Effect of plant species . . . . . . . . . . . . 6

4. Competition and antagonism .......... 7

4.1 Organisms succession during residue decomposition . . 7

4.2 Interactions with soil microorganisms . . . . . . 7

4.3 Fusarium species displacement on residues . . . . 8

4.4 Interactions with the soil fauna . . . . . . . 8

5. Importance of agricultural practices for the disease development ................... 9

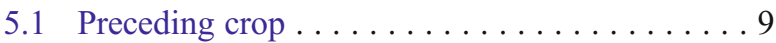

5.2 Soil tillage $\ldots \ldots \ldots \ldots \ldots \ldots \ldots \ldots$

5.3 Fertilization and pesticides . . . . . . . . 10

6. Conclusion ................... 11

\section{Introduction}

Wheat (Triticum aestivum L. ssp. aestivum) is the second most cultivated crop in the world after maize (Zea mays L.). In 2010, 653 million tons of wheat and durum wheat were produced in the world, of which 140.7 million tons were produced in Europe (FAO 2011). Moreover, the wheat is one of the most traded crops worldwide, with 125.9 million tons traded in 2010 (AGPB 2012). The cultural practices trends due to economical and environmental reasons, i.e., reduction of soil tillage and pesticides use, raise the issue of re-emerging wheat diseases, such as fungal diseases (McMullen et al. 1997; Millennium Ecosystem Assessment 2005).

Studies of plant pathogenic fungi generally focus on infection processes, disease development and other concerns in plant-microorganism interactions, but the saprotrophic period of these pathogens' life cycle is not well known. Most soil fungi are decomposers or saprotrophs that feed on decaying organic material. In fact, they play a key role in the decomposition of organic polymers that takes place in the soil. Fungi are considered primary decomposers in forests, where litter contains high concentrations of complex polymers. Fungi have a unique role in the degradation of plant-derived woody substrates containing lignocellulose, i.e., cellulose complexed with lignin (Finlay 2007; Sinsabaugh 2005). They also play an important role in arable soils by breaking down and recycling plant residues, primarily cellulose and hemicellulose (Stromberg 2005). Among them, some plant pathogenic fungi take place and their role should be considered. Indeed, plant pathogenic fungi are categorised as either biotrophs or necrotrophs, and as either obligate pathogens or facultative saprotrophs. For example, the disease cycle of the deleterious fungus Fusarium graminearum (Fig. 1), the anamorph stage of Gibberella zeae (Schwein.) Petch is well studied (Trail 2009). In a previous review, Goswami and Kistler (2004) provided an update on the pathogenesis, genetics, evolution and genomics of $F$. graminearum but the ecological requirements of its saprotrophic stage are less well understood.

Fusarium head blight, root rot and foot rot (crown rot) are diseases that cause significant yield loss in several crops worldwide such as wheat (Fig. 2), maize, oat (Avena sativa L.), barley (Hordeum vulgare L.) and rice (Oryza sativa L.) (Parry et al. 1995; Pereyra and Dill-Macky 2008; Trail et al. 2003). Yield losses caused by Fusarium head blight in Northern and Central America from 1998 to 2002 were evaluated to reach $\$ 2.7$ billion (Nganje et al. 2002). Several species are involved in the fungal complex that causes these diseases. Many of them also produce mycotoxins, such as deoxynivalenol (commonly known as DON) and its acetylated forms 3-acetyl-4-deoxynivalenol (3-ADON) and 15acetyl-4-deoxynivalenol (15-ADON), nivalenol (NIV) and zearalenone (ZEA) (Desjardins and Proctor 2007). These mycotoxins are of major concern because of their effect on human and animal health and because they persist during storage and are heat-resistant (JEFCA 2001). The threshold of these mycotoxins in foodstuffs is regulated in Europe since 2007 (CE N¹881/2006). Among the species involved in the complex causing Fusarium disease on wheat, F. graminearum predominates in many parts of the world (Bottalico 1998; Bottalico and Perrone 2002; Parry et al. 1995).

Like other Fusarium species in the complex, F. graminearum survives saprotrophically on crop residues in the absence of its hosts (Sutton 1982). Fusarium head blight severity and deoxynivalenol contamination significantly increase with the density of residues left from the preceding crop (Blandino et al. 2010). Moreover, surface residues provide a substrate for active growth of $F$. graminearum for a longer period of time than buried residues (Pereyra et al. 2004). Burying F. graminearum-infested crop residues deeper in the soil can efficiently reduce $F$. graminearum populations; however, the pathogen may survive for several years. During the decomposition process, the chemical composition and the availability of the plant material changes as some resources are used up while others are made available for saprotrophic growth. To survive over time, F. graminearum has to be able to use available resources and to compete with the different organisms that are invading the material, each of them being specific for each of the decomposition 

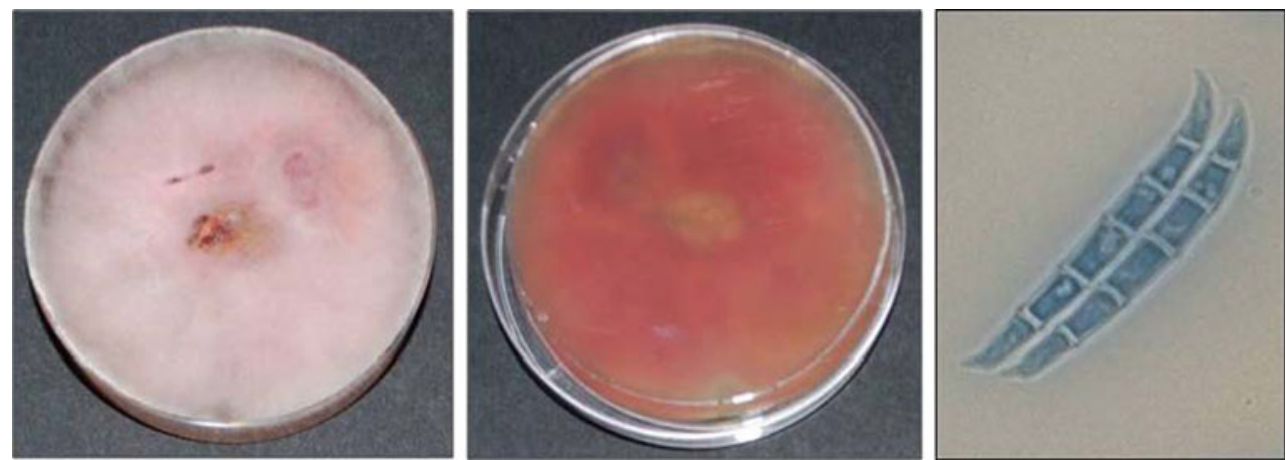

Fig. 1 Macroscopic and microscopic pictures of Fusarium graminearum, the causal agent of Fusarium head blight (photograph: courtesy of J. Leplat). Macroscopic pictures were taken after growth on potato dextrose agar. The undersurface shows the typical carmine red color of $F$. graminearum species. The microscopic picture shows macroconidia

stages. To develop control strategies of $F$. graminearum primary inoculum, a better understanding of the complex interactions that determine its ability to grow and compete for crop residues is needed.

This review focuses on the saprotrophic phase of the life cycle of F. graminearum. Discussion includes several topics: (1) how environmental factors affect its saprotrophic survival; (2) in which ways crop residues provide a habitat for it and impact on its survival depending on their quantity and on plant species they come from; (3) whether crop residue colonization by it is a matter of competition and antagonism; and (4) what is the incidence of agricultural practices on its survival.

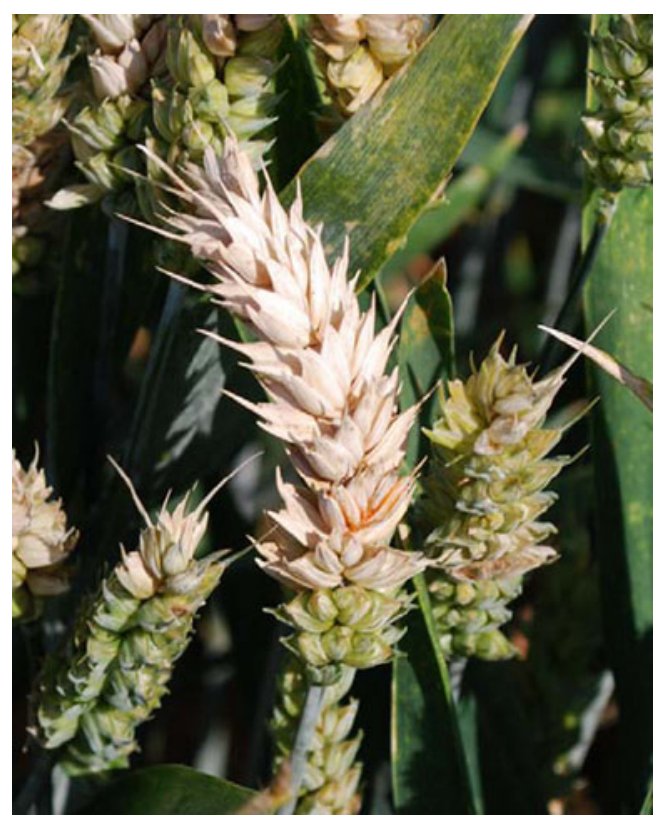

Fig. 2 Wheat ear infested by Fusarium graminearum (photograph: courtesy of J. Leplat). The ear shriveling suggests a low grains filling inferring yield losses. The orange spikelet is due to $F$. graminearum growth suggesting mycotoxins production with the typical spindle shape which gives its name to the Fusarium genus. The cylindrical shape of the macroconidia, i.e., dorsal and ventral surfaces parallel, and the foot shape of the basal cell are typical of $F$. graminearum species

\section{Fusarium graminearum}

\subsection{Fusarium diseases on wheat}

On wheat, Fusarium fungi cause several distinct diseases (Colbach et al. 1996; Kohl et al. 2007). First, seedling diseases, which cause damping-off, seedling blight, and foot rot. In Europe and North America, these symptoms are mainly due to Microdochium nivale (Fr.) Samuels \& I.C. Hallet, but F. culmorum (Wm.G. Sm.) Sacc., F. graminearum and F. pseudograminearum O'Donnell \& T. Aoki are also frequently associated depending on the geographical conditions and climatic conditions (Bateman 1993; Smiley et al. 2005). Second, Fusarium head blight, which is the mature plant disease caused by a complex of species. The Fusarium species predominantly found in Europe are $F$. graminearum, F. avenaceum (Fr.) Sacc. and F. culmorum (Bottalico 1998; Bottalico and Perrone 2002; Nielsen et al. 2011a, b). A survey conducted in France between 2000 and 2002 showed that, in addition to $F$. graminearum, F. avenaceum and $F$. poae (Peck) Wollenw. were also found regularly, whereas $M$. nivale and $F$. culmorum were less frequent than previously recorded. Other species, such as $F$. tricinctum (Corda) Sacc., F. sambucinum Fuckel, F. equiseti (Corda) Sacc., F. acuminatum Ellis \& Everh. and F. sporotrichioides Sherb., were found in lower quantities (Ioos et al. 2004). The composition, the development and the structure of the Fusarium community depend on a combination of factors, among which climate plays a major role (Muller et al. 2010). F. graminearum, together with several other encountered species, can produce toxigenic compounds (Bottalico 1998). Like the other Fusarium species associated with Fusarium head blight, $F$. graminearum overwinters in soil and on infested crop residues (Fernandez et al. 2008; Pereyra and Dill-Macky 2008; Sutton 1982). The mycelium on crop residues allows the production of both macroconidia 
(asexual spores) and ascospores (sexual spores produced in perithecia), which constitute the primary inoculum that causes primary infection of wheat heads (Parry et al. 1995; Shaner 2003; Yuen and Schoneweis 2007; Fig. 3).

$F$. graminearum is one of the predominant species involved in Fusarium diseases. F. graminearum overwinters on crop residues which provide the primary inoculum for Fusarium head blight development. Therefore, a better knowledge of $F$. graminearum survival on crop residues is important to control this disease development.

\subsection{Saprotrophic growth}

Cell-wall degrading enzymes produced by plant pathogenic fungi are considered important during the pathogenic part of the life cycle and may also be relevant during the saprotrophic part (Belien et al. 2006; Van den Brink and de Vries 2011). In the case of $F$. graminearum, scanning electron micrographs and immuno-labelling showed that the fungus penetrates and invades its hosts by secreting cell-walldegrading enzymes (Kikot et al. 2009). The plant cell-wall components cellulose, xylan, and pectin are damaged when they are in direct contact with the pathogen growing interand intracellularly in the tissues of wheat spikelets (Wanjiru et al. 2002). Kikot et al. (2010) examined F. graminearum isolates for their production of different extracellular enzymes with activities of potential biotechnological interest: pectinases (polygalacturonase and polymethylgalacturonase), cellulase (carboxymethylcellulase) and hemicellulase (xylanase). Although enzymatic activities varied among the different isolates, polygalacturonase activity was evidenced early (after 2 days' incubation in the presence of oat bran) and was the highest for all isolates. Only some of the isolates showed a high level of polymethylgalacturonase activity; carboxymethylcellulase and endoxylanase activities were particularly high at late stages, i.e., after 4 and 7 days' incubation, respectively, and their maximum values were lower than pectinase values (Kikot et al. 2010). The production of these enzymes

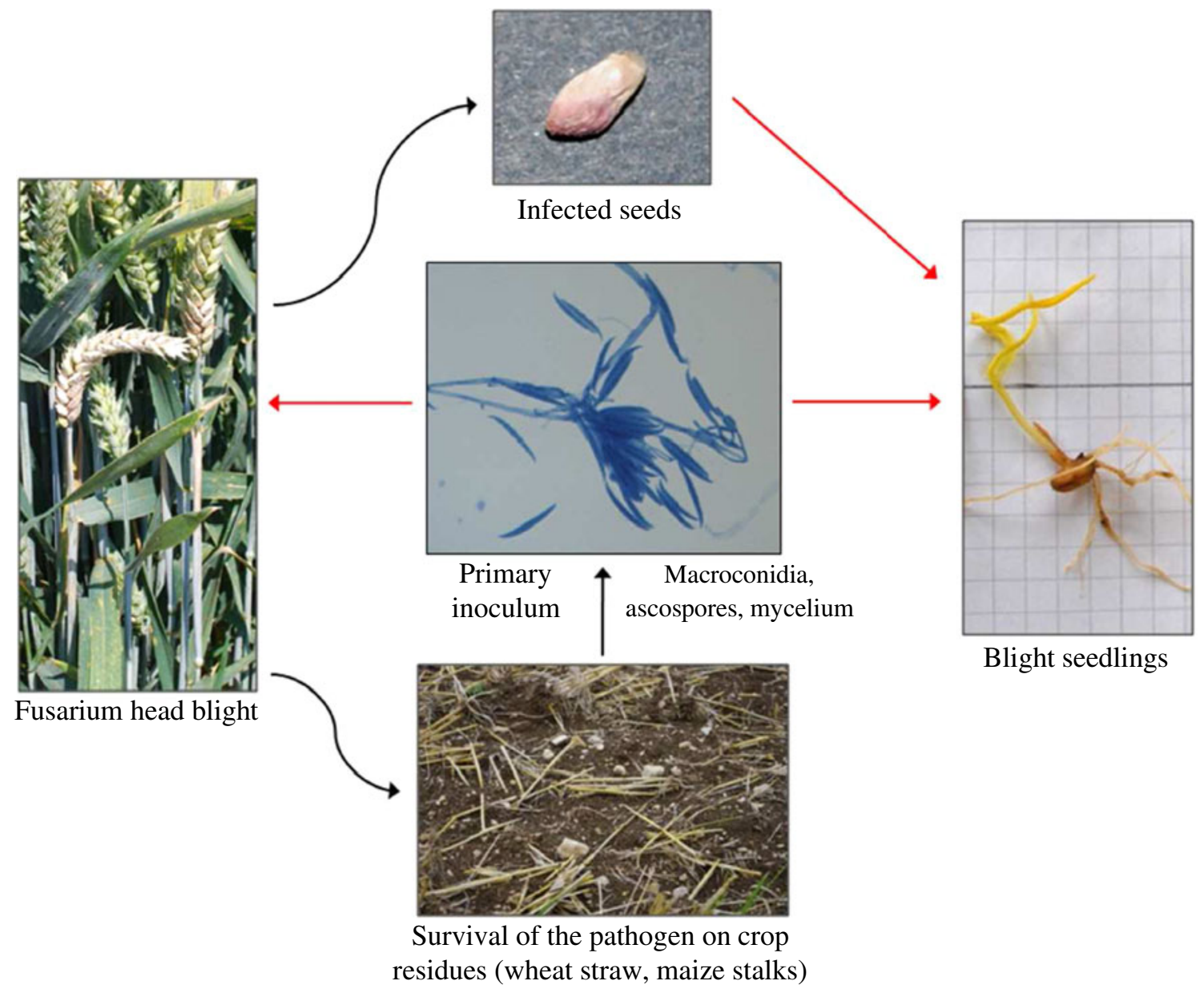

Fig. 3 Disease cycle of Fusarium graminearum. Black, sigmoid-like arrows indicate habitats provided by the crop and red arrows indicate infectious activity kept up by habitats (photograph: courtesy of J. Leplat). Crop residues allow the production of $F$. graminearum primary inoculum. The primary inoculum can provoke seedling blight as well as Fusarium head blight by splash dispersal. F. graminearum-infested wheat ears can cause the production of infected seeds which lead to seedling blight 
requires inducers that are likely to be present in the substrate and regulated by various mitogen-activated proteins (MAP) kinases, some of which have already been identified (Jenczmionka and Schafer 2005). Besides being factors involved during infection, these polysaccharide-degrading enzymes are also important for the colonisation of crop residues.

The chemical composition of crop biomass differs from one plant species to another and from one plant part to another. This may influence the decomposition of the crop residues by microbial colonisers, and thereby the saprotrophic survival of pathogens such as $F$. graminearum (Khonga and Sutton 1988; Nicolardot et al. 2007). There are also consequences on soil organic $\mathrm{C}$ inputs, which have been discussed elsewhere (Johnson et al. 2007). A comparative screening of $F$. graminearum exoproteome on culture media containing glucose or hop (Humulus lupulus $\mathrm{L}$.) showed that the number of enzymes secreted by the fungus was higher in the presence of plant material (Phalip et al. 2005). Eightyfour proteins were identified on medium containing hops, whereas only 23 were identified on medium containing glucose. Among them, 11 degraded cellulose, 19 degraded pectin and 25 degraded hemicellulose. Two amylases and two chitinases were also identified. Obviously, F. graminearum has the enzymatic ability to degrade compounds of the primary cell wall. Moreover, 30 xylanase-related genes were transcribed in the presence of different carbon sources, i.e., hop cell wall, xylan, xylose or carboxymethylcellulose, with different expression patterns for a specific enzyme, which suggests that $F$. graminearum can also adapt to a range of variations in its environment (Hatsch et al. 2006).

Briefly, F. graminearum can overwinter on crop residues thanks to its enzymatic ability to degrade and use these residues as nutrients.

\subsection{Environmental factors controlling saprotrophic survival}

Temperature, water activity and other physico-chemical factors can influence the different aspects of residues colonisation by $F$. graminearum. Its growth and the germination of conidia and ascospores are favoured by warm, humid conditions. Ramirez et al. (2006) found that the mycelial growth of two strains of $F$. graminearum reached an optimum at $25^{\circ} \mathrm{C}$ at water activities ranging between 0.950 and 0.995 , and that no growth was observed below $5^{\circ} \mathrm{C}$. Both strains were able to grow in drier conditions, at a minimum water activity of 0.900 . By contrast, when the water activity was maintained at high levels, overall microbial activity was stimulated, resulting in a rapid decrease in the quantity of $F$. graminearum on wheat and maize residues buried in the soil (Burgess and Griffin 1968). Soil characteristics such as soil compaction affect water availability. M. nivale caused more foot rot in a non-compacted soil than in a compacted soil, probably due to reduced water availability leading to poor fungal development and mobility (Colbach et al. 1996; Toyota et al. 1996).

Inch and Gilbert (2003a) studied the maturation of $F$. graminearum sexual structures on damaged kernels of wheat at three different temperatures. Even if the fungus survives at $-10^{\circ} \mathrm{C}$, perithecia are only formed between $2^{\circ} \mathrm{C}$ and $20^{\circ} \mathrm{C}$ and ascospores only appear at $20^{\circ} \mathrm{C}$. The optimal temperature range for the maturation of perithecia is between $15.0^{\circ} \mathrm{C}$ and $28.5^{\circ} \mathrm{C}$, whereas the optimum for the production of ascospores is between $25^{\circ} \mathrm{C}$ and $28^{\circ} \mathrm{C}$ at high water activity (Dufault et al. 2006; Sutton 1982; Tschanz et al. 1976).

The optimal temperature for the production of compounds such as mycotoxins is different. For two strains of $F$. graminearum, mycotoxin production was highest at a temperature of $30^{\circ} \mathrm{C}$ at a water activity of 0.995 (Ramirez et al. 2006). Deoxynivalenol was only produced at water activities between 0.950 and 0.995 even though growth was possible between 0.900 and 0.995 , which indicates that mycotoxin production requires more specific conditions than growth.

Although $F$. graminearum can survive on residues buried 20 to $25 \mathrm{~cm}$ deep for more than 4 years, it can only develop on plant debris in the upper centimetres of the soil (Champeil et al. 2004). In addition to favourable temperature and water availability, its development depends on soil aeration (Cassini 1970). Furthermore, some stages of its life cycle require light. For example, perithecia initiation and ascospore production are light-dependent (Gilbert and Tekauz 2000; Sutton 1982; Tschanz et al. 1976). A F. graminearum survival test on damaged kernels left on the soil surface or buried in the first layer of the soil at 5- and $10-\mathrm{cm}$ depths for 24 months showed that perithecia were produced at all depths but ascospores were only formed at the soil surface (Inch and Gilbert 2003a).

Soil characteristics such as $\mathrm{pH}$ could also have an effect on F. graminearum survival. A negative correlation between soil $\mathrm{pH}$ values ranging between 4.4 and 6.4, and the amount of crown rot on wheat has been found, but it was not clear whether this is because F. graminearum has a better saprotrophic capacity in acidic soils or because it is more aggressive under these conditions (Smiley et al. 1996). Although mycelial growth and conidial germination were limited under acidic and alkaline conditions, $F$. graminearum could grow on media whose $\mathrm{pH}$ values range between 4 and 10 (Thompson et al. 1993). Macroconidia germination on solid media reached almost $100 \%$ after $18 \mathrm{~h}$ at $\mathrm{pH}$ values ranging between 3 and 7 (Beyer et al. 2004). The time needed for freshly discharged ascospores to germinate and the rate of ascospore germination were both affected by the $\mathrm{pH}$. The time required for $50 \%$ of the viable ascospores to germinate was shortest at $\mathrm{pH} 3.5$, and ascospore germination was highest at $\mathrm{pH}$ 3.7. Changing the $\mathrm{pH}$ from 3.7 to 2.5 and from 3.7 to 6.5 decreased the germination of ascospores by $66 \%$ and $56 \%$, respectively (Beyer and Verreet 2005). This 
might explain the better saprotrophic capacity of the fungus in soil at $\mathrm{pH} 4.4$ than in soil at $\mathrm{pH} 6.4$.

Although $F$. graminearum can survive when exposed to unfavourable environmental conditions, its growth and the development of its sexual reproduction structures require sufficient temperature, water, light and $\mathrm{O}_{2}$ availabilities.

\section{Effect of crop residues as $F$. graminearum growth substrates in the soil}

\subsection{Effect of crop residues quantities}

There is a general relationship between the yield of a given crop and the amount of residues left on the ground after harvesting. In most cases, the residues/yield ratio is between 1 and 2 (Kumar et al. 2003; Scarlat et al. 2011). The amount of residue may vary from 2 to 9 tons $\mathrm{ha}^{-1}$, depending on the type of crop: in rape (Brassica napus L.), barley and wheat leaves, values were 2.0, 2.5 and 3.5 tons residues $\mathrm{ha}^{-1}$, respectively, whereas in alfalfa (Medicago sativa L.) and maize leaves they were 8.5 and 9.0 tons residues ha ${ }^{-1}$, respectively (Morel 1996; Vilain 1989). Part of the residues is exported for further transformation (e.g., animal bedding, animal feed and biofuel production; Berndes et al. 2003); however, a large part of them is left in and on the soil (Malhi et al. 2011). The residues are either ploughed down (inversion tillage) or left at the surface when conservation tillage is being practiced, as in zero-tillage or other types of noninversion tillage. Non-inversion tillage may increase wheat grain infection by $F$. graminearum as compared to inversion tillage whereby residues are buried in the soil. The effects vary to a great extent with climatic conditions and preceding crop type (Blandino et al. 2010; Fernandez et al. 2008). In conservation tillage, more than $30 \%$ of the soil surface is covered by crop residues (Bockus and Shroyer 1998). Steinkellner and Langer (2004) found up to $9.10^{3}$ colonyforming units of $F$. graminearum and of $F$. culmorum $\mathrm{g}^{-1}$ of soil when non-inversion tillage was used, whereas ten times as few colony-forming units were found after 20-cm deep inversion tillage. F. graminearum and F. culmorum survival is favoured by high quantities of available residues (Bateman et al. 1998). For example, maize production results in large amounts of residues which promote the production of inoculum (Champeil et al. 2004). Comparing four different densities of maize residues left on the soil surface showed that disease severity and deoxynivalenol occurrence in wheat grains both increased with residue quantity (Blandino et al. 2010; Maiorano et al. 2008).

To sum up, F. graminearum survival is enhanced by important quantities of available crop residues, which depends on the production capacity of the preceding crop and on the crop residues management.

\subsection{Effect of plant species}

Not only can climatic conditions and residue quantities influence $F$. graminearum development, but the nature of crop residues can also affect its biology. For example, wheat and durum wheat produce similar amounts of residues, but wheat infection is more severe after durum wheat than after wheat (Champeil et al. 2004). The production of reproductive structures also varies with the plant species. Pereyra and Dill-Macky (2008) found the induction of a higher ascospore production on wheat and barley than on maize or on some selected weed species (i.e., Digitaria sanguinalis (L.) Scop., Setaria spp., Lolium multiflorum Lam. and Cynodon dactylon (L.) Pers.), while no ascospore production was found on sunflower (Helianthus annuus L.) residues. Similarly, inoculum production varies over time, and depends on the plant part. F. graminearum survival on maize stems and ears on the one hand and on wheat stems, spikelets and grains on the other hand, was compared over 3 years. The length of macroconidia and perithecia production varied according to the type of residue. For example, perithecia were produced on all types of residues during the first year, while only wheat spiklets and grains allowed the perithecia production during the third year. (Khonga and Sutton 1988). Similarly, the amount of Fusarium was found to decrease faster on wheat internodes than on stem bases, and faster on nodes than on internodes (Kohl et al. 2007; Pereyra et al. 2004). Finally, F. graminearum ascospore production was higher on kernels than on nodes and floral bracts (Pereyra and Dill-Macky 2005). These observations can be partly explained by the chemical composition of the residues and particularly by their $\mathrm{C} / \mathrm{N}$ ratio: the $\mathrm{C} / \mathrm{N}$ ratio varies over time depending on the decomposition stage of the residues, and influences growth and the production of macroconidia and sexual structures. For example, the $\mathrm{C} / \mathrm{N}$ value of wheat straw is high (134), whereas the $\mathrm{C} / \mathrm{N}$ value of wheat leaves is ten times as low (13.4; Nicolardot et al. 2001). Macroconidia are produced on residues that are in the early stage of decomposition whereas perithecia production occurs later, when decomposition is much more advanced and growth conditions are less favourable. Rich residues with a low $\mathrm{C} / \mathrm{N}$ ratio (such as maize stems, maize kernels, wheat spikelets and lowly infested wheat grains) provide a favourable habitat, allowing longer saprotrophic development before perithecia production, as compared to poor residues with a high $\mathrm{C} / \mathrm{N}$ ratio, such as wheat stems and severely infested wheat grains (Khonga and Sutton 1988).

Briefly, F. graminearum survival depends on the $\mathrm{C} / \mathrm{N}$ ratio of the residues, and consequently on the plant species, on the plant part and on the degradation rate of the residues. $F$. graminearum survival is enhanced by rich residues, with a low $\mathrm{C} / \mathrm{N}$ ratio. $F$. graminearum 
sexual reproductive structures appear on residues with high $\mathrm{C} / \mathrm{N}$, when growth conditions are less favourable to fungal development.

\section{Competition and antagonism}

\subsection{Organisms' succession during residue decomposition}

Organisms of different species and from different trophic groups are involved at different stages of the decomposition process (Frankland 1998; Thirup et al. 2001). The ability of a specific species to grow or survive on the material depends on its ability to use the nutrients available at a particular decomposition stage and on its ability to compete for them with other organisms that are colonising the material concomitantly. Among these groups, microarthropods, nematodes, protozoa, bacteria and fungi have important predatorprey interactions that may determine community assemblages during the early decomposition of crop residues depending on their nature (Ponge 2005). The fungal community seems to be the least affected by such interactions (Georgieva et al. 2005a), and the increase in fungal biomass that occurs later during succession is more correlated with the decomposition of different crop residues (Georgieva et al. 2005b). Therefore controlling the decomposition process could represent a way of controlling primary inoculum quantities of soil- and residue-borne plant pathogenic fungi such as $F$. graminearum. The succession of fungal populations and the decomposition process are also affected by external factors such as climatic conditions and agronomic practices, which may determine the competitive exclusion among the complex of Fusarium species (Doohan et al. 2003; Fernandez et al. 2008). Crop residues present in the soil or at the soil surface are degraded by a wide range of organisms that use the material for their growth. Larger soil organisms such as microarthropods and earthworms fragment the plant material, thereby making it more available for microbial degradation. In general, weak and aggressive pathogens dominate during the initial stages of degradation. Later, the material is more and more colonised by fungi that are specialised for saprotrophic growth (Frankland 1998; Kjöller and Struwe 2002). Fresh residue-colonising microorganisms are copiotrophs, which can be considered as rstrategists using easily available carbon sources and maximising their intrinsic growth rate when resources are abundant (Pianka 1970). The microorganisms that colonise residues at later stages of decomposition are oligotrophs, which can be considered as K-strategists. Compared with $\mathrm{r}$-strategists, K-strategists have a slower growth rate, a better ability to degrade recalcitrant organic substances and better survival rates when resources are limited (Bastian et al. 2009).
To sum up, the decomposition of the crop residues is a complex process involving the whole soil biota. F. graminearum survival can be controlled by driving the balance of this process.

\subsection{Interactions with soil microorganisms}

By applying the $\mathrm{r}$ - and $\mathrm{K}$-strategy concept to the comparison of the different microorganisms involved in crop residues decomposition, we could consider F. graminearum as an rstrategist during its saprotrophic phase because it can grow rapidly when fresh matter is available. This can be linked to the enzymes it excretes in the presence of plant material. The many cellulases, hemicellulases and pectinases that $F$. graminearum produces are important early in the decomposition process (Phalip et al. 2005). The relative abundance of $F$. graminearum can be decreased rapidly by keeping the humidity of wheat residues at a high level, which favours the activity of other microbes and can hence hamper $F$. graminearum growth (Burgess and Griffin 1968). Indeed, F. graminearum seems to be a poor competitor over time, particularly compared with other Fusarium species. For instance, the amount of $F$. graminearum found on wheat residues rapidly decreases whereas those of $F$. solani (Mart.) Sacc., F. oxysporum Schlecht., F. poae and F. sporotrichioides increase. All these species are known to have better saprotrophic capacity in crop residues or in soil than $F$. graminearum (Pereyra and Dill-Macky 2008). Nevertheless, $F$. graminearum can survive on residues for more than 24 months (Pereyra et al. 2004). Fusarium poae and F. sporotrichioides, also involved in Fusarium head blight, are less aggressive than $F$. graminearum on plants, but they have a better saprotrophic capacity and can outcompete other organisms on residues (Fernandez et al. 2008). Few studies have been carried out about the interactions that occur among the different pathogens on residues in the field, but experiments in controlled conditions emphasise how specific these interactions are (Simpson et al. 2004; Velluti et al. 2000). F. culmorum growth and M. nivale var. majus growth were both limited when the strains were grown together in the same liquid medium, compared with their respective growth rates when they were inoculated alone (Simpson et al. 2004). On wheat seedlings, F. culmorum thoroughly inhibited $M$. nivale var. nivale and var. majus growth; however, when M. nivale var. majus was established before F. culmorum, it cosuppressed $F$. culmorum growth. Similarly, the presence of $F$. graminearum reduced $F$. moniliforme and $F$. proliferatum (T. Matsushima) Nirenberg growth on sterile maize grains, whereas its own growth was not affected by the other two species (Velluti et al. 2000).

Moreover, intraspecific diversity of phenotypic traits within $F$. graminearum species leads to interactions between F. graminearum populations for crop residues colonisation. 
This can be revealed through different levels of aggressiveness or different chemotypes among any given set of $F$. graminearum strains interacting with host plants. This can also be revealed through the intrinsic competitive skills used by different $F$. graminearum populations to rapidly colonise and efficiently exploit crop residues such as maize stalks (Miedaner et al. 2004; Naef and Defago 2006).

The role of deoxynivalenol - and of mycotoxins in general - in the multitrophic interactions $F$. graminearum faces during its saprotrophic growth, is poorly understood. While the deleterious impact on animals, including humans, is rather well studied (Nielsen et al. 2011a, b; Pestka 2010; Sampietro et al. 2010), the impact it might have on soil organisms has less been considered (Abid et al. 2011). The different studies results are conflicting. In some cases, mycotoxins have been shown to have antimicrobial activities against Trichoderma atroviride P. Karst. (Lutz et al. 2003), and a possible regulatory role in bacterial-fungal interactions has been proposed (Duffy and Defago 1997), but in other case, the comparison of toxigenic and nontoxigenic $F$. graminearum strains showed that there was no evidence that deoxynivalenol played a role in the defence against T. atroviride (Naef et al. 2006). Moreover, the potential impact of mycotoxins on the microflora can be reduced by bacteria able to degrade these mycotoxins (Awad et al. 2010; Fuchs et al. 2002). Therefore the putative competitive advantage mycotoxins might confer to $F$. graminearum versus other antagonistic colonisers remains to be demonstrated.

F. graminearum seems to be a poor competitor over time for crop residues colonisation, even among Fusarium species. The enhancement of the residues decomposition processes by other organisms could be efficient to limit $F$. graminearum survival.

\subsection{Fusarium species displacement on residues}

It is possible to limit $F$. graminearum survival and growth on residues by adding microorganisms that can outcompete it. Already known biocontrol agents like T. atroviride and $T$. harzianum Rifai (Naef et al. 2006), or Clonostachys rosea (Link) Schroers, Samuels, Seifert and W. Gams (Gromadzka et al. 2009) are among the possible candidates. It is also possible to screen species isolated from residues (Luongo et al. 2005; Singh et al. 2009). The latter approach increases the likelihood that the microorganisms are adapted to the environment of the studied residues. Magan and Lynch (1986) tested ten fungal isolates for their capacity to colonise straw residues at different temperatures and at different water potentials. Among them, only Penicillium spp. and $F$. culmorum were able to grow at a low water potential, confirming the role played by water availability in competitive interactions. T. harzianum, F. equiseti and F. nygamai L.W.
Burgess \& Trimboli, which were all isolated from wheat stubble, have been shown to reduce $F$. pseudograminearum growth on culture medium (Singh et al. 2009). The displacement of $F$. pseudograminearum by these fungal isolates on barley straw was tested at different temperatures $\left(5-35^{\circ} \mathrm{C}\right)$ and at different water potentials $(-0.3$ to $-5.0 \mathrm{MPa})$. $T$. harzianum was the most efficient antagonist but displaced $F$. pseudograminearum very poorly at low temperatures and low water potentials. F. equiseti and F. nygamai gave moderate displacement. F. equiseti was the most efficient at low temperatures and low water potentials, showing that field conditions need to be taken into account when looking for an efficient antagonistic agent. C. rosea isolates were found to suppress sporulation of $F$. graminearum and $F$. culmorum on wheat straw and to suppress sporulation of $F$. graminearum, $F$. culmorum, $F$. proliferatum and $F$. verticillioides (Sacc.) Nirenberg on maize stalks under controlled conditions. When tested under field conditions, however, their efficiency was limited (Luongo et al. 2005).

With regard to sexual reproduction, a Microsphaeropsis sp. isolate significantly reduced ascospore production by $F$. graminearum on wheat and maize residues under controlled conditions (Bujold et al. 2001). Microsphaeropsis sp. suppressed ascospore production when inoculated on wheat residues 2 weeks before the pathogen was inoculated, concomitantly, or 4 weeks later. Furthermore, it still suppressed ascospore production when inoculated on maize residues 6 weeks after the pathogen. However, Microsphaeropsis sp. significantly reduced the production of perithecia on crop residues under field conditions at only a few sampling dates. This highlights once again that although the antagonist can be found efficient under laboratory conditions, field application may not be so easy.

Along with their effect on pathogen growth and sporulation, competitors for residues can also decrease mycotoxin production. When $T$. atroviride and $F$. graminearum were inoculated together on autoclaved maize leaves, deoxynivalenol production by $F$. graminearum was $36 \%$ lower per biomass unit of the pathogenic fungus than when F. graminearum was inoculated alone (Naef et al. 2006).

To sum up, the use of specific outcompeting microorganisms could be an efficient option to limit $F$. graminearum survival on crop residues. Several fungal species with an interesting effect under laboratory conditions were identified. However, the field efficiency of these fungal strains is still limited, highlighting the difficulties to transpose laboratory experiments to field application.

\subsection{Interactions with the soil fauna}

The soil animals influence pathogenic fungi and other soil microbes directly by feeding on them and by dispersing them. They also have an indirect influence: they alter the 
physical environment by fragmenting organic matter, burrowing through the soil, mixing it and by depositing faeces (Brown 1995; Coleman and Crossley 1996; Swift et al. 1979). The soil fauna is often divided up into groups, which is useful for understanding how animals move within the soil and influence soil structure and other abiotic and biotic conditions (Coleman and Crossley 1996; Lavelle and Spain 2001; Swift et al. 1979). The smaller soil animals grazing on mycelia with selective feeding habits have an important influence on saprotrophically growing fungi. The larger soil animals, which are less selective in their feeding habits, are important consumers of plant residues and soil. Their main influence can probably be seen through their effects on the fragmentation of organic material and on soil mixing (Friberg et al. 2005).

Anecic earthworms, such as Lumbricus terrestris L. and Aporrectodea longa Ude, which take fresh litter from the soil surface and pull it down into the soil through their burrows, can reduce the quantities of fungal pathogens such as Fusarium spp. (Moody et al. 1996). The fact that infested wheat straw with high levels of deoxynivalenol was incorporated faster than straw with low levels of deoxynivalenol shows that deoxynivalenol is not repellent for L. terrestris and possibly attractive (Oldenburg et al. 2008). Earthworms also grew better on infested straw than on non-infested straw, either because the decomposition by $F$. graminearum made compounds in the straw more easily available or because the fungal biomass itself was a source of nutrients for them. Since, fungal biomass and deoxynivalenol degradation increased in the presence of earthworms, it is possible that earthworms take part in deoxynivalenol degradation, maybe through the activity of their associated gut microorganisms (Schrader et al. 2009).

It seems that soil animals able to feed on $F$. graminearuminfested crop residues could participate in $F$. graminearum survival control.

\section{Importance of agricultural practices for the disease development}

\subsection{Preceding crop}

The preceding crop is an important factor determining the risk for Fusarium diseases on wheat (Blandino et al. 2010; Klem et al. 2007; Muller et al. 2010). If the preceding crop is a good host of the pathogen, the disease risk increases due to the inoculum initially present on the crop. The severity of Fusarium head blight caused by $F$. graminearum on wheat and the amount of mycotoxins produced have been found higher after maize than after soya, and continuous wheat cropping implied a higher risk of crown rot development caused by $F$. graminearum than a wheat-pea or wheat- fallow rotation (Dill-Macky and Jones 2000; Smiley et al. 1996; Teich and Hamilton 1985). Variations also exist among host plants: the disease is more severe after maize or durum wheat than after wheat or barley due to the quantities of residues produced and to their chemical composition. Schaafsma et al. (2005) found the number of viable propagules trapped at anthesis in wheat fields planted on maize or wheat stubble higher than the number of viable propagules in wheat fields following non-host crops, and the highest number of propagules was found after maize.

The composition of the fungal community causing Fusarium head blight changes depending on the preceding crop. In a survey performed in New Zealand on the community composition of Fusarium fungi isolated from harvested wheat grains in relation to the preceding crop, F. graminearum was recovered, along with $F$. avenaceum, F. poae and $F$. culmorum (Cromey et al. 2002). In each case, F. graminearum was the most common species. F. graminearum quantities were highest after maize, whereas $F$. avenaceum and $F$. poae quantities were highest after other crops. Where crown rot and Fusarium head blight were caused by F. graminearum and F. culmorum, the stem-bases were more frequently colonised by F. culmorum than by $F$. graminearum, but the situation was reversed on ears. And in this case, after maize, the stem-base disease was generally reduced whereas head blight increased (Bateman et al. 2007).

Most studies about the effects of different preceding crops on the development of Fusarium fungi were carried out on crops that are classically included in major rotation systems, such as wheat, maize or rape (Dill-Macky and Jones 2000; Klem et al. 2007; Muller et al. 2010). It could be worth assessing the role of specific, less frequently studied intermediate crops such as Indian mustard (Brassica juncea (L.) Czern \& Coss), which has been shown to suppress F. graminearum growth (Kirkegaard et al. 1996; Sarwar et al. 1998).

Briefly, preceding crop is an important factor in the development of Fusarium head blight on wheat. Using a host of the disease as preceding crop carries a risk. Indeed, $F$. graminearum could settle on crop residues, in particular in case of maize which produces high quantities of residues. More care must be paid to the crop rotation scheme to limit the risk of Fusarium head blight development.

\subsection{Soil tillage}

Inversion tillage generally decreases the risk of Fusarium head blight compared with non-inversion tillage (DillMacky and Jones 2000; Fernandez et al. 2008; Steinkellner and Langer 2004). Several factors can explain why tillage can affect plant disease. Infection caused by splash dispersal 
during rainfalls or overhead irrigation is increased in the presence of large amounts of infested crop residues at the soil surface (Bateman 2005; Osborne and Stein 2007; Sutton 1982). Bateman (2005) found that the presence of plant material infested by F. culmorum on the soil surface 34 weeks before anthesis was necessary to cause infection on ears. As for the preceding crop, tillage can have different effects on the different diseases caused by the same pathogens spectrum. In a study comparing disease on stem-bases and on ears, infection on stem-bases, mainly caused by $F$. culmorum, was decreased by non-inversion tillage, whereas infection on ears, mainly caused by $F$. graminearum, was increased (Bateman et al. 2007). However, a test using plating method to determine whether the quantity of $F$. culmorum in a soil sampled to a $10-\mathrm{cm}$ depth was affected by soil tillage showed that the number of propagules per gram of soil was higher with non-inversion tillage than with inversion tillage (Bateman et al. 1998). As already mentioned, the fungus can survive in soil for a extend periods (more than 2 years) despite low $\mathrm{O}_{2}$ availability and unfavourable abiotic conditions, but it cannot grow or produce ascospores (Champeil et al. 2004; Khonga and Sutton 1988).

Tillage has an effect on the decomposition rate of residues. Decomposition of buried residues is faster and more complete than decomposition of surface residues. Pereyra et al. (2004) found that for wheat residues that were buried for 24 months, only $2 \%$ of dry matter remained, whereas $25 \%$ remained when the residues were left at the soil surface. In a comparative study between barley straw and red clover foliage (Trifolium pratense L.), the limited contact between the soil matrix and the residues affected decomposition dynamics, particularly in the case of straw residues, which are rich in cellulose and hemicelluloses (Henriksen and Breland 2002). This slow decomposition may be due to insufficient colonisation and growth of holocellulosedegrading microorganisms. The influence of soil tillage on the composition of microbial communities was confirmed by the analysis of bacterial and fungal communities during the decomposition process. The genetic structure of communities on residues is specific to residue location within the soil (soil surface or incorporated in soil; Nicolardot et al. 2007). Comparison of buried and non-buried residues showed that the quantity of $F$. graminearum inoculum was twice as high on non-buried residues as on buried residues. Indeed, a slower decomposition at the soil surface allows a longer-lasting availability of nutrients that are essential for F. graminearum development (Pereyra et al. 2004). A positive effect of reduced tillage is that the soil fauna is better preserved and can play a more active role in the decomposition and mineralization of crop residues, thus limiting habitats for saprotrophically surviving plant pathogenic fungi.
Different tillage practices affect the presence of weeds. Weeds can be a source of inoculum: in particular, F. graminearum inoculum has been found on Festuca, D. sanguinalis, Setaria spp., L. multiflorum and C. dactylon. When $F$. graminearum was the most common isolated species, other fungi belonging to the complex such as $F$. avenaceum, $F$. sambucinum and F. poae were also found (Pereyra and DillMacky 2008). Over the years, the composition of fungi causing Fusarium head blight founds on weeds changes. In a study by Inch and Gilbert (2003b), F. graminearum was found on 11 out of 34 grass species investigated. F. sporotrichioides, $F$. equiseti, $F$. avenaceum, $F$. culmorum and $F$. poae were isolated too, but only $F$. graminearum and $F$. sporotrichioides were isolated in June. In July, F. equiseti and $F$. culmorum were isolated in addition to $F$. graminearum and F. sporotrichioides, while in August, all species were isolated. Although weed removal has been an important part in the control of different fungal plant diseases for many decades (Mantle et al. 1977; Miedaner et al. 2011), it is clear that the reduction soil tillage and sustainable pesticide use are clearly going to bring about with them a new focus on the role of weeds in Fusarium head blight mediation (Landschoot et al. 2011; Postic et al. 2012).

Shortly, soil tillage is an important factor in the development of Fusarium head blight on wheat. Inversion tillage reduces the risk of disease development in comparison to non-inversion tillage. Inversion tillage (1) hides the primary inoculum infecting wheat ears and prevents splash dispersal, (2) enhances the residues decomposition process and thus limits F. graminearum survival, and (3) allows controlling weed species which could be a source of $F$. graminearum inoculum.

\subsection{Fertilization and pesticides}

The fungi in the complex causing Fusarium head blight are able to use all forms of nitrogen; however, the effects of fertilizers are mainly indirect and mediated via increased plant vigour (Huber and Watson 1974). Different forms of nitrogen have different effects on the survival of pathogenic Fusarium spp. On one hand, in some cases, the number of propagules of $F$. culmorum in the soil and of $F$. graminearum on residues increases with inorganic nitrogen fertilization and with the application of calcium ammonium nitrate, respectively (Bateman and Coskun 1995; Lemmens et al. 2004; Yi et al. 2002). On the other hand, urea can hinder the reproduction of fungi, inhibit the formation of chlamydospores and also prevent ascospore maturation (Teich 1989).

The herbicides used can influence inoculum levels. As weeds can be inoculum source, applying herbicides could reduce the risks of disease break-outs; however, little information is available about the direct effect of herbicides on $F$. graminearum, or about the way its saprotrophic ability could 


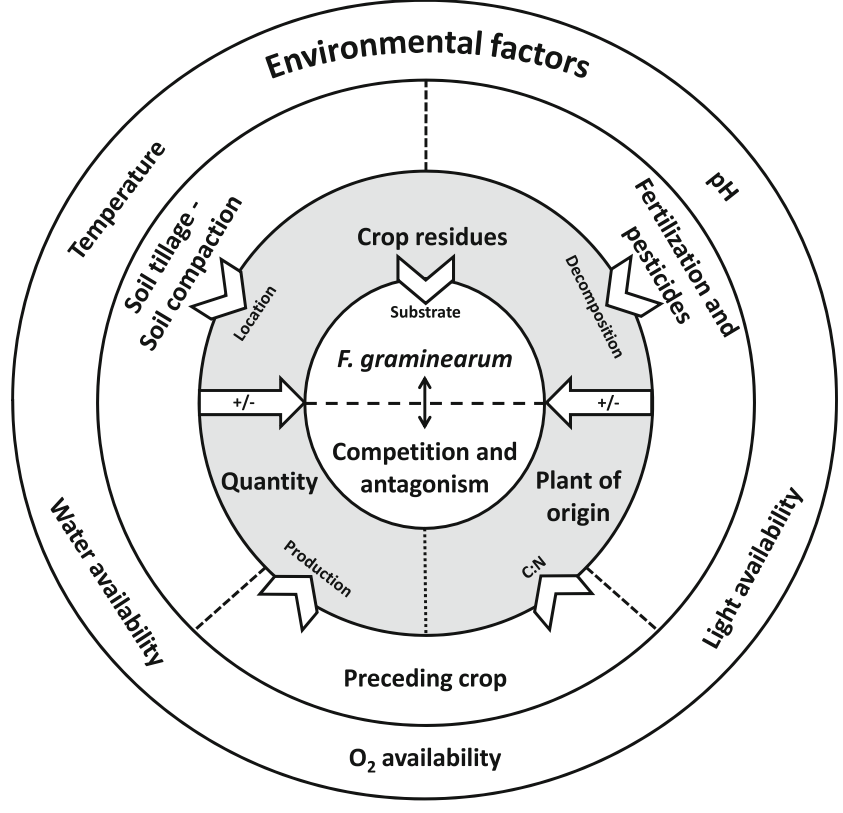

Fig. 4 Saprotrophic survival of Fusarium graminearum. Crop residues are the main habitat of F. graminearum. On the one hand, they provide spatial and trophic resources the fungus has to exploit in interaction with the rest of the microflora and the soil fauna. On the other hand, they buffer the impact of environmental factors, including agricultural practices

be affected by their presence. Some glyphosate-based herbicides can stimulate $F$. avenaceum and $F$. graminearum growth, under in vitro conditions as well as on crop residues in the field, which leads to an increase in wheat stem-base and ear infections (Fernandez et al. 2009; Hanson and Fernandez 2003). Weed control with glyphosate seems to provide a source of energy for Fusarium leading to a proliferation of populations. The numbers of other fungal species decrease when glyphosate is used, suggesting important changes in the structure of fungal communities that should in turn affect their functioning.

Data from European surveys have recently shown that organically produced cereal grains have an equal or a lower level of Fusarium-generated mycotoxins than conventionally produced cereals (Bernhoft et al. 2010; Birzele et al. 2002; Edwards 2009; Meister 2009). There are currently no clear explanations for that fact, but one factor may be differences in the microflora associated with the different cropping systems.

To summarise, little is known about the effect of fertilizers and pesticides on F. graminearum saprotrophic survival. Some glyphosate-based herbicides may stimulate $F$. graminearum survival by changing the structure of fungal communities and providing a source of energy.

\section{Conclusion}

An important part of the life cycle of $F$. graminearum, the main causal agent of Fusarium head blight, takes place outside the plant. The fungus produces an array of enzymes which allow it to use crop residues as a trophic and spatial resource for its saprotrophic development.

Figure 4 shows the proposed model exposing the role of the various factors that affect $F$. graminearum survival on crop residues. Depending on environmental factors, it is able to survive on crop residues, grow, and produce conidia and sexual structures which provide the primary inoculum causing disease on wheat heads. The development of $F$. graminearum is favoured by the presence of large amounts of residues and by nutrient rich residues, with a low $\mathrm{C} / \mathrm{N}$ ratio. Since $F$. graminearum appears to be a poor competitor over time compared to other organisms that colonise crop residues, strategies based on competition for the growth substrate could be an efficient way to control the production of primary inoculum. Some fungal species have been found to suppress sporulation and ascospore production by $F$. graminearum under controlled conditions in that way, but their efficiency still remains to be confirmed under field conditions. In addition, strategies that favour residue decomposition, via the activity of the soil's microflora and fauna, may reduce $F$. graminearum survival.

Since $F$. graminearum overwinters on crop residues, agricultural practices including crop rotation and residue management play a large part in Fusarium head blight management. Primary inoculum production can be limited by using a non-host plant as a preceding crop. Inversion tillage buries the primary inoculum and thus prevents inoculum being splashed up to wheat heads. In addition, inversion tillage favours the decomposition of crop residues in comparison with non-inversion tillage. Finally, inversion tillage makes it possible to control the source of $F$. graminearum inoculum provided by weed species.

Acknowledgements This review is part of a $\mathrm{PhD}$ work funded by the Vitagora-FUI programme Farine+2007-11. We thank the Swedish Farmers' Foundation for Agricultural Research (SLF) and La Fondation Franco-Suédoise for financing H. Friberg. We are grateful to P. Mangin and L. Falchetto (INRA, UE Epoisses-France) for fruitful discussions. We thank A. Buchwalter and C. Woods, proofreaders, for correcting the English language.

\section{References}

Abid M, Leplat J, Fayolle L, Gautheron E, Heraud C, Gautheron N, Edel-Hermann V, Cordier C, Steinberg C (2011) Ecological role of mycotoxins in wheat crop residues: consequences on the multitrophic interactions and the development of Fusarium graminearum. In: Multitrophic interactions in soil. IOBC Bull 71:1-5

Awad WA, Ghareeb K, Bohm J, Zentek J (2010) Decontamination and detoxification strategies for the Fusarium mycotoxin deoxynivalenol in animal feed and the effectiveness of microbial biodegradation. Food Addit Contam Part A Chem 27(4):510-520. doi:10.1080/19440040903571747 
Bastian F, Bouziri L, Nicolardot B, Ranjard L (2009) Impact of wheat straw decomposition on successional patterns of soil microbial community structure. Soil Biol Biochem 41(2):262-275. doi:10.1016/j.soilbio.2008.10.024

Bateman GL (1993) Development of disease symptoms and fungal patogens on shoot bases in continuous winter-wheat, and effects of fungicides. Plant Pathol 42(4):595-608. doi:10.1111/j.13653059.1993.tb01540.x

Bateman GL (2005) The contribution of ground-level inoculum of Fusarium culmorum to ear blight of winter wheat. Plant Pathol 54(3):299-307. doi:10.1111/j.1365-3059.2005.01181.x

Bateman GL, Coskun H (1995) Populations of Fusarium spp. in soil growing continuous winter wheat, and effects of long-term application of fertilizers and of straw incorporation. Mycol Res 99:1391-1394. doi:10.1016/S0953-7562(09),81227-6

Bateman GL, Murray G, Gutteridge RJ, Coskun H (1998) Effects of method of straw disposal and depth of cultivation on populations of Fusarium spp. in soil and on brown foot rot in continuous winter wheat. Ann Appl Biol 132(1):35-47. doi:10.1111/j.1744 7348.1998.tb05183.x

Bateman GL, Gutteridge RJ, Gherbawy Y, Thomsett MA, Nicholson P (2007) Infection of stem bases and grains of winter wheat by Fusarium culmorum and $F$. graminearum and effects of tillage method and maize-stalk residues. Plant Pathol 56(4):604-615. doi:10.1111/j.1365-3059.2007.01577.x

Belien T, Van Campenhout S, Robben J, Volckaert G (2006) Microbial endoxylanases: Effective weapons to breach the plant cell-wall barrier or, rather, triggers of plant defense systems? Mol Plant Microbe Interact 19(10):1072-1081. doi:10.1094/mpmi-19-1072

Berndes G, Hoogwijk M, van den Broek R (2003) The contribution of biomass in the future global energy supply: a review of 17 studies. Biomass Bioenerg 25(1):1-28. doi:10.1016/s0961-9534(02) 00185-x

Bernhoft A, Clasen PE, Kristoffersen AB, Torp M (2010) Less Fusarium infestation and mycotoxin contamination in organic than in conventional cereals. Food Addit Contam Part A Chem 27 (6):842-852. doi:10.1080/19440041003645761

Beyer M, Verreet JA (2005) Germination of Gibberella zeae ascospores as affected by age of spores after discharge and environmental factors. Eur J Plant Pathol 111(4):381-389. doi:10.1007/ s10658-004-6470-9

Beyer M, Roding S, Ludewig A, Verreet JA (2004) Germination and survival of Fusarium graminearum macroconidia as affected by environmental factors. J Phytopathol 152(2):92-97. doi:10.1111/ j.1439-0434.2003.00807.x

Birzele B, Meier A, Hindorf H, Kramer J, Dehne HW (2002) Epidemiology of Fusarium infection and deoxynivalenol content in winter wheat in the Rhineland, Germany. Eur J Plant Pathol 108 (7):667-673. doi:10.1023/a:1020632816441

Blandino M, Pilati A, Reyneri A, Scudellari D (2010) Effect of maize crop residue density on Fusarium head blight and on deoxynivalenol contamination of common wheat grains. Cereal Res Commun 38(4):550-559. doi:10.1556/crc.38.2010.4.12

Bockus WW, Shroyer JP (1998) The impact of reduced tillage on soilborne plant pathogens. Annu Rev Phytopathol 36:485-500. doi:10.1146/annurev.phyto.36.1.485

Bottalico A (1998) Fusarium diseases of cereals: species complex and related mycotoxin profiles, in Europe. J Plant Pathol 80(2):85103. doi:10.4454/jpp.v80i2.807

Bottalico A, Perrone G (2002) Toxigenic Fusarium species and mycotoxins associated with head blight in small-grain cereals in Europe. Eur J Plant Pathol 108(7):611-624. doi:10.1023/ A:1020635214971

Brown GG (1995) How do earthworms affect microfloral and faunal community diversity. Plant Soil 170(1):209-231. doi:10.1007/ BF02183068
Bujold I, Paulitz TC, Carisse O (2001) Effect of Microsphaeropsis sp. on the production of perithecia and ascospores of Gibberella zeae. Plant Dis 85(9):977-984. doi:10.1094/PDIS.2001.85.9.977

Burgess LW, Griffin DM (1968) The recovery of Gibberella zeae from wheat straws. Aust J Exp Agric Anim Husb 8(32):364-370

Cassini R (1970)Facteurs favorables ou défavorables au développement des fusarioses et septorioses du blé. In: Meeting of Sections Cereals and Physiology, Dijon, 1970. Eucarpia, pp 271-279

Champeil A, Dore T, Fourbet JF (2004) Fusarium head blight: epidemiological origin of the effects of cultural practices on head blight attacks and the production of mycotoxins by Fusarium in wheat grains. Plant Sci 166(6):1389-1415. doi:10.1016/ j.plantsci.2004.02.004

Colbach N, Maurin N, Huet P (1996) Influence of cropping system on foot rot of winter wheat in France. Crop Prot 15(3):295-305. doi:10.1016/0261-2194(95),00150-6

Coleman DC, Crossley DA Jr (1996) Fundamentals of soil ecology. Academic Press, London

Cromey MG, Shorter SC, Lauren DR, Sinclair KI (2002) Cultivar and crop management influences on Fusarium head blight and mycotoxins in spring wheat (Triticum aestivum) in New Zealand. N Z J Crop Hortic Sci 30(4):235-247. doi:10.1080/ 01140671.2002.9514220

Association Générale des Producteurs de Blé (2012) Récoltes. http:// www.agpb.fr/documentation-et-publications/recoltes/

Desjardins AE, Proctor RH (2007) Molecular biology of Fusarium mycotoxins. Int J Food Microbiol 119:47-50. doi:10.1016/ j.ijfoodmicro.2007.07.024

Dill-Macky R, Jones RK (2000) The effect of previous crop residues and tillage on Fusarium head blight of wheat. Plant Dis 84(1):7176. doi:10.1094/PDIS.2000.84.1.71

Doohan FM, Brennan J, Cooke BM (2003) Influence of climatic factors on Fusarium species pathogenic to cereals. Eur J Plant Pathol 109(7):755-768. doi:10.1023/a:1026090626994

Dufault NS, De Wolf ED, Lipps PE, Madden LV (2006) Role of temperature and moisture in the production and maturation of Gibberella zeae perithecia. Plant Dis 90(5):637-644. doi:10.1094/ pd-90-0637

Duffy BK, Defago G (1997) Zinc improves biocontrol of Fusarium crown and root rot of tomato by Pseudomonas fluorescens and represses the production of pathogen metabolites inhibitory to bacterial antibiotic biosynthesis. Phytopathology 87(12):1250 1257. doi:10.1094/phyto.1997.87.12.1250

Edwards SG (2009) Fusarium mycotoxin content of UK organic and conventional wheat. Food Addit Contam Part A Chem 26(4):496506. doi:10.1080/02652030802530679

FAO (2011) Food Outlook Report. November 2011. p. 186. FAO Trade and Markets Division. http://www.fao.org/giews/, Rome, Italy

Fernandez MR, Huber D, Basnyat P, Zentner RP (2008) Impact of agronomic practices on populations of Fusarium and other fungi in cereal and noncereal crop residues on the Canadian Prairies. Soil Tillage Res 100(1-2):60-71. doi:10.1016/j.still.2008.04.008

Fernandez MR, Zentner RP, Basnyat P, Gehl D, Selles F, Huber D (2009) Glyphosate associations with cereal diseases caused by Fusarium spp. in the Canadian Prairies. Eur J Agron 31(3):133143. doi:10.1016/j.eja.2009.07.003

Finlay RD (2007) The Fungi in soil. In: Elsas JD, Jansson J, Trevors JT (eds) Modern soil microbiology. CRC Press, New York, pp 107-146

Frankland JC (1998) Fungal succession - unravelling the unpredictable. Mycol Res 102:1-15. doi:10.1017/S0953756297005364

Friberg H, Lagerlöf J, Ramert B (2005) Influence of soil fauna on fungal plant pathogens in agricultural and horticultural systems. Biocontrol Sci Technol 15(7):641-658. doi:10.1080/ 09583150500086979

Fuchs E, Binder EM, Heidler D, Krska R (2002) Structural characterization of metabolites after the microbial degradation of type A 
trichothecenes by the bacterial strain BBSH 797. Food Addit Contam 19(4):379-386. doi:10.1080/02652030110091154

Georgieva S, Christensen S, Petersen H, Gjelstrup P, ThorupKristensen K (2005a) Early decomposer assemblages of soil organisms in litterbags with vetch and rye roots. Soil Biol Biochem 37(6):1145-1155. doi:10.1016/j.soilbio.2004.11.012

Georgieva S, Christensen S, Stevnbak K (2005b) Nematode succession and microfauna-microorganism interactions during root residue decomposition. Soil Biol Biochem 37(10):1763-1774. doi:10.1016/ j.soilbio.2005.02.010

Gilbert J, Tekauz A (2000) Review: recent developments in research on fusarium head blight of wheat in Canada. Can J Plant Pathol Rev Can Phytopathol 22(1):1-8. doi:10.1080/ 07060660009501155

Goswami RS, Kistler HC (2004) Heading for disaster: Fusarium graminearum on cereal crops. Mol Plant Pathol 5:515-525. doi:10.1111/J.1364-3703.2004.00252

Gromadzka K, Chelkowski J, Popiel D, Kachlicki P, Kostecki M, Golinski P (2009) Solid substrate bioassay to evaluate the effect of Trichoderma and Clonostachys on the production of zearalenone by Fusarium species. World Mycotoxin J 2(1):45-52. doi:10.3920/WMJ2008.x046

Hanson KG, Fernandez MR (2003) Effect of glyphosate herbicides on Pyrenophora tritici-repentis and other cereal pathogens. In: Proceedings of Fourth International Wheat Tan Spot and Spot Blotch Workshop, Bemidji, MN, USA, 21-24 July, 2002, 2003. Agricultural Experiment Station, North Dakota State University, pp 128-131

Hatsch D, Phalip V, Petkovski E, Jeltsch JM (2006) Fusarium graminearum on plant cell wall: No fewer than 30 xylanase genes transcribed. Biochem Biophys Res Commun 345(3):959-966. doi:10.1016/bbrc.2006.04.171

Henriksen TM, Breland TA (2002) Carbon mineralization, fungal and bacterial growth, and enzyme activities as affected by contact between crop residues and soil. Biol Fertil Soils 35(1):41-48. doi:10.1007/s00374-001-0438-0

Huber DM, Watson RD (1974) Nitrogen form and plant disease. Annu Rev Phytopathol 12:139-165. doi:10.1146/annurev.py.12. 090174.001035

Inch SA, Gilbert J (2003a) Survival of Gibberella zeae in Fusariumdamaged wheat kernels. Plant Dis 87(3):282-287. doi:10.1094/ PDIS.2003.87.3.282

Inch S, Gilbert J (2003b) The incidence of Fusarium species recovered from inflorescences of wild grasses in southern Manitoba. Can J Plant Pathol Rev Can Phytopathol 25(4):379-383. doi:10.1080/ 07060660309507093

Ioos R, Belhadj A, Menez M (2004) Occurrence and distribution of Microdochium nivale and Fusarium species isolated from barley, durum and soft wheat grains in France from 2000 to 2002. Mycopathologia 158(3):351-362. doi:10.1007/s11046-0042228-3

Jenczmionka NJ, Schafer W (2005) The Gpmk1 MAP kinase of Fusarium graminearum regulates the induction of specific secreted enzymes. Curr Genet 47(1):29-36. doi:10.1007/s00294004-0547-z

Johnson JMF, Barbour NW, Weyers SL (2007) Chemical composition of crop biomass impacts its decomposition. Soil Sci Soc Am J 71 (1):155-162. doi:10.2136/sssaj2005.0419

Joint FAO/WHO Expert Committee on Food Additives (2001) Safety evaluation of certain mycotoxins in food. FAO Food and Nutrition Paper (74)

Khonga EB, Sutton JC (1988) Inoculum production and survival of Gibberella zeae in maize and wheat residues. Plant Pathol 10:232-239. doi:10.1080/07060668809501730

Kikot GE, Hours RA, Alconada TM (2009) Contribution of cell wall degrading enzymes to pathogenesis of Fusarium graminearum: a review. J Basic Microbiol 49(3):231-241. doi:10.1002/jobm.200800231

Kikot GE, Hours RA, Alconada TM (2010) Extracellular enzymes of Fusarium graminearum isolates. Braz Arch Biol Technol 53 (4):779-783. doi:10.1590/s1516-89132010000400005

Kirkegaard JA, Wong PTW, Desmarchelier JM (1996) In vitro suppression of fungal root pathogens of cereals by Brassica tissues. Plant Pathol 45(3):593-603. doi:10.1046/j.1365-3059.1996.d01-143.x

Kjöller AH, Struwe S (2002) Fungal communities, succession, enzymes, and decomposition. In: Burns RG, Dick RP (eds) Enzymes in the environment: activity, ecology, and applications. Marcel Dekker, New York, pp 267-284

Klem K, Vanova M, Hajslova J, Lancova K, Sehnalova M (2007) A neural network model for prediction of deoxynivalenol content in wheat grain based on weather data and preceding crop. Plant Soil Environ 53(10):421-429

Kohl J, de Haas BH, Kastelein P, Burgers S, Waalwijk C (2007) Population dynamics of Fusarium spp. and Microdochium nivale in crops and crop residues of winter wheat. Phytopathology 97 (8):971-978. doi:10.1094/phyto-97-8-0971

Kumar A, Cameron JB, Flynn PC (2003) Biomass power cost and optimum plant size in western Canada. Biomass Bioenerg 24 (6):445-464. doi:10.1016/s0961-9534(02)00149-6

Landschoot S, Audenaert K, Waegeman W, Pycke B, Bekaert B, De Baets B, Haesaert G (2011) Connection between primary Fusarium inoculum on gramineous weeds, crop residues and soil samples and the final population on wheat ears in Flanders, Belgium. Crop Prot 30(10):1297-1305. doi:10.1016/ j.cropro.2011.05.018

Lavelle P, Spain AV (2001) Soil ecology. Kluwer Academic Publishers, Dordrecht

Lemmens M, Haim K, Lew H, Ruckenbauer P (2004) The effect of nitrogen fertilization on Fusarium head blight development and deoxynivalenol contamination in wheat. J Phytopathol 152(1):18. doi:10.1046/j.1439-0434.2003.00791.x

Luongo L, Galli M, Corazza L, Meekes E, De Haas L, Van der Plas CL, Kohl J (2005) Potential of fungal antagonists for biocontrol of Fusarium spp. in wheat and maize through competition in crop debris. Biocontrol. Sci Technol 15(3):229-242. doi:10.1080/ 09583150400016852

Lutz MP, Feichtinger G, Defago G, Duffy B (2003) Mycotoxigenic Fusarium and deoxynivalenol production repress chitinase gene expression in the biocontrol agent Trichoderma atroviride P1. Appl Environ Microbiol 69(6):3077-3084. doi:10.1128/ aem.69.6.3077-3084.2003

Magan N, Lynch JM (1986) Water potentiel, growth and cellulolysis of fungi involved in decomposition of cereal residues. J Gen Microbiol 132:1181-1187. doi:10.1099/00221287-132-5-1181

Maiorano A, Blandino M, Reyneri A, Vanara F (2008) Effects of maize residues on the Fusarium spp. infection and deoxynivalenol (DON) contamination of wheat grain. Crop Prot 27(2):182-188. doi:10.1016/j.cropro.2007.05.004

Malhi SSMSS, Nyborg M, Goddard T, Puurveen D (2011) Long-term tillage, straw and $\mathrm{N}$ rate effects on quantity and quality of organic $\mathrm{C}$ and $\mathrm{N}$ in a Gray Luvisol soil. Nutr Cycl Agroecosyst 90(1):120. doi:10.1007/s10705-010-9399-8

Mantle PG, Shaw S, Doling DA (1977) Role of weed grasses in etiology of ergot disease in wheat. Ann Appl Biol 86(3):339351. doi:10.1111/j.1744-7348.1977.tb01848.x

McMullen M, Jones R, Gallenberg D (1997) Scab of wheat and barley: A re-emerging disease of devastating impact. Plant Dis 81 (12):1340-1348. doi:10.1094/PDIS.1997.81.12.1340

Meister U (2009) Fusarium toxins in cereals of integrated and organic cultivation from the Federal State of Brandenburg (Germany) harvested in the years 2000-2007. Mycotoxin Res 25(3):133139. doi:10.1007/s12550-009-0017-z 
Miedaner T, Schilling AG, Geiger HH (2004) Competition effects among isolates of Fusarium culmorum differing in aggressiveness and mycotoxin production on heads of winter rye. Eur J Plant Pathol 110(1):63-70. doi:10.1023/B:EJPP.0000010136.38523.a9

Miedaner T, Klocke B, Flath K, Geiger HH, Weber WE (2011) Diversity, spatial variation, and temporal dynamics of virulences in the German leaf rust (Puccinia recondita $\mathrm{f}$. $s p$ secalis) population in winter rye. Eur J Plant Pathol 132(1):23-35. doi:10.1007/s10658011-9845-8

Millennium Ecosystem Assessment (2005) Ecosystems and human well-being: synthesis. Island Press, Washington

Moody SA, Piearce TG, Dighton J (1996) Fate of some fungal spores associated with wheat straw decomposition on passage through the guts of Lumbricus terrestris and Aporrectodea longa. Soil Biol Biochem 28(4-5):533-537. doi:10.1016/0038-0717(95) 00172-7

Morel R (1996) Cultivated soils; Les sols cultivés - Technique et documentation, 2nd edn. Lavoisier, Paris

Muller MEH, Brenning A, Verch G, Koszinski S, Sommer M (2010) Multifactorial spatial analysis of mycotoxin contamination of winter wheat at the field and landscape scale. Agric Ecosyst Environ 139(1-2):245-254. doi:10.1016/j.agee.2010.08.010

Naef A, Defago G (2006) Population structure of plant-pathogenic Fusarium species in overwintered stalk residues from Bttransformed and non-transformed maize crops. Eur J Plant Pathol 116(2):129-143. doi:10.1007/s10658-006-9048-x

Naef A, Senatore M, Defago G (2006) A microsatellite based method for quantification of fungi in decomposing plant material elucidates the role of Fusarium graminearum DON production in the saprophytic competition with Trichoderma atroviride in maize tissue microcosms. FEMS Microbiol Ecol 55(2):211-220. doi:10.1111/j.1574-6941.2005.00023.x

Nganje IB, Bangsund DA, Leistritz FL, Wilson WW, Tiapo NM (2002) Estimating the economic impact of crop disease: the case of Fusarium head blight in U.S. wheat and barley. In: 2002 National Fusariul Head Blight Forum. Michigan State University, East Lansing, pp 275-281

Nicolardot B, Recous S, Mary B (2001) Simulation of C and N mineralisation during crop residue decomposition: a simple dynamic model based on the C:N ratio of the residues. Plant Soil 228(1):83-103. doi:10.1023/a:1004813801728

Nicolardot B, Bouziri L, Bastian F, Ranjard L (2007) A microcosm experiment to evaluate the influence of location and quality of plant residues on residue decomposition and genetic structure of soil microbial communities. Soil Biol Biochem 39(7):1631-1644. doi:10.1016/j.soilbio.2007.01.012

Nielsen JKS, Vikstroem AC, Turner P, Knudsen LE (2011a) Deoxynivalenol transport across the human placental barrier. Food Chem Toxicol 49:2046-2052. doi:10.1016/j.fct.2011.05.016

Nielsen LK, Jensen JD, Nielsen GC, Jensen JE, Spliid NH, Thomsen IK, Justesen AF, Collinge DB, Jorgensen LN (2011b) Fusarium head blight of cereals in Denmark: species complex and related mycotoxins. Phytopathology 101(8):960-969. doi:10.1094/ phyto-07-10-0188

Oldenburg E, Kramer S, Schrader S, Weinert J (2008) Impact of the earthworm Lumbricus terrestris on the degradation of Fusariuminfected and deoxynivalenol-contaminated wheat straw. Soil Biol Biochem 40(12):3049-3053. doi:10.1016/j.soilbio.2008.09.004

Osborne LE, Stein JM (2007) Epidemiology of Fusarium head blight on small-grain cereals. Int J Food Microbiol 119(1-2):103-108. doi:10.1016/j.ijfoodmicro.2007.07.032

Parry DW, Jenkinson P, McLeod L (1995) Fusarium ear blight (scab) in small-grain cereals - a review. Plant Pathol 44(2):207-238. doi:10.1111/j.1365-3059.1995.tb02773.x

Pereyra SA, Dill-Macky R (2005) Colonization and inoculum production of Gibberella zeae in components of wheat residue. Cereal Res Commun 33(4):755-762. doi:10.1556/ CRC.33.2005.2-3.145

Pereyra SA, Dill-Macky R (2008) Colonization of the residues of diverse plant species by Gibberella zeae and their contribution to Fusarium head blight inoculum. Plant Dis 92(5):800-807. doi:10.1094/pdis-92-5-0800

Pereyra SA, Dill-Macky R, Sims AL (2004) Survival and inoculum production of Gibberella zeae in wheat residue. Plant Dis 88 (7):724-730. doi:10.1094/PDIS.2004.88.7.724

Pestka JJ (2010) Deoxynivalenol: mechanisms of action, human exposure, and toxicological relevance. Arch Toxicol 84(9):663-679. doi:10.1007/s00204-010-0579-8

Phalip V, Delalande F, Carapito C, Goubet F, Hatsch D, Leize-Wagner E, Dupree P, Van Dorsselaer A, Jeltsch JM (2005) Diversity of the exoproteome of Fusarium graminearum grown on plant cell wall. Curr Genet 48(6):366-379. doi:10.1007/s00294-005-0040-3

Pianka E (1970) On r- and K-selection. Am Nat 104:592-597

Ponge JF (2005) Fungal communities: relation to resource succession. In: Dighton J, White JF, Oudemans P (eds) The fungal community: its organisation and role in the ecosystem. Taylor \& Francis, New York, pp 169-180

Postic J, Cosic J, Vrandecic K, Jurkovic D, Saleh AA, Leslie JF (2012) Diversity of Fusarium species isolated from weeds and plant debris in Croatia. J Phytopathol 160(2):76-81. doi:10.1111/ j.1439-0434.2011.01863.x

Ramirez ML, Chulze S, Magan N (2006) Temperature and water activity effects on growth and temporal deoxynivalenol production by two Argentinean strains of Fusarium graminearum on irradiated wheat grain. Int J Food Microbiol 106(3):291-296. doi:10.1016/j.ijfoodmicro.2005.09.004

Sampietro DA, Marin P, Iglesias J, Presello DA, Vattuone MA, Catalan CAN, Gonzalez Jaen MT (2010) A molecular based strategy for rapid diagnosis of toxigenic Fusarium species associated to cereal grains from Argentina. Fungal Biol 114:74-81. doi:10.1016/ j.mycres.2009.10.008

Sarwar M, Kirkegaard JA, Wong PTW, Desmarchelier JM (1998) Biofumigation potential of brassicas - III. In vitro toxicity of isothiocyanates to soil-borne fungal pathogens. Plant Soil 201 (1):103-112. doi:10.1023/a:1004381129991

Scarlat N, Blujdea V, Dallemand JF (2011) Assessment of the availability of agricultural and forest residues for bioenergy production in Romania. Biomass Bioenerg 35(5):1995-2005. doi:10.1016/ j.biombioe.2011.01.057

Schaafsma AW, Tamburic-Ilincic L, Hooker DC (2005) Effect of previous crop, tillage, field size, adjacent crop, and sampling direction on airborne propagules of Gibberella zeael Fusarium graminearum, Fusarium head blight severity, and deoxynivalenol accumulation in winter wheat. Can J Plant Pathol Rev Can Phytopathol 27(2):217-224. doi:10.1080/ 07060660509507219

Schrader S, Kramer S, Oldenburg E, Weinert J (2009) Uptake of deoxynivalenol by earthworms from Fusarium-infected wheat straw. Mycotoxin Res 25(1):53-58. doi:10.1007/s12550-009$0007-1$

Shaner G (2003) Epidemiology of Fusarium head blight of small grain cereals in North America. In: Leonard KJ, Bushnell WR (eds) Fusarium head blight of wheat and barley. American Phytopathological Society Press, St. Paul, MN, pp 84-119

Simpson DR, Thomsett MA, Nicholson P (2004) Competitive interactions between Microdochium nivale var. majus, M. nivale var. nivale and Fusarium culmorum in planta and in vitro. Environ Microbiol 6(1):79-87. doi:10.1046/j.1462-2920.2003.00540.x

Singh DP, Backhouse D, Kristiansen P (2009) Interactions of temperature and water potential in displacement of Fusarium pseudograminearum from cereal residues by fungal antagonists. Biol Control 48(2):188-195. doi:10.1016/j.biocontrol.2008.10.015 
Sinsabaugh RL (2005) Fungal enzymes at the community scale. In: Dighton J, White JF, Oudemans P (eds) The fungal community: its organisation and role in the ecosystem. Taylor \& Francis, New York, pp 349-360

Smiley RW, Collins HP, Rasmussen PE (1996) Diseases of wheat in long-term agronomic experiments at Pendleton, Oregon. Plant Dis 80(7):813-820. doi:10.1094/PD-80-0813

Smiley RW, Gourlie JA, Easley SA, Patterson LM (2005) Pathogenicity of fungi associated with the wheat crown rot complex in Oregon and Washington. Plant Dis 89(9):949-957. doi:10.1094/pd-89-0949

Steinkellner S, Langer I (2004) Impact of tillage on the incidence of Fusarium spp. in soil. Plant Soil 267(1-2):13-22. doi:10.1007/ s11104-005-2574-Z

Stromberg ME (2005) Fungal communities of agroecosystems. In: Dighton J, White JF, Oudemans P (eds) The fungal community: its organisation and role in the ecosystem. Taylor \& Francis, New York, pp 813-822

Sutton JC (1982) Epidemiology of wheat head blight and maize ear rot caused by Fusarium graminearum. Can J Plant Pathol Rev Can Phytopathol 4:195-209. doi:10.1080/07060668209501326

Swift MJ, Heal OW, Anderson JM (1979) Decomposition in terrestrial ecosystems. Blackwell Scientific Publications, Oxford

Teich AH (1989) Epidemiology of wheat (Triticum aestivum L.) scab caused by Fusarium spp. In: Chelkovski J (ed) Fusarium: mycotoxins, taxonomy and pathogenicity. Elsevier Science, Amsterdam, pp 269-282

Teich AH, Hamilton JR (1985) Effect of cultural practices, soil phosphorus, potassium, and $\mathrm{pH}$ on the incidence of Fusarium head blight and deoxynivalenol levels in wheat. Appl Environ Microbiol 49(6):1429-1431

Thirup L, Johnsen K, Torsvik V, Spliid NH, Jacobsen CS (2001) Effects of fenpropimorph on bacteria and fungi during decomposition of barley roots. Soil Biol Biochem 33(11):1517-1524. doi:10.1016/s0038-0717(01)00067-0

Thompson DP, Metevia L, Vessel T (1993) Influence of $\mathrm{pH}$ alone and in combination with phenolic antioxydants on growth and germination of mycotoxigenic species of Fusarium and Penicillium. J Food Prot 56(2):134-138
Toyota K, Young IM, Ritz K (1996) Effects of soil matric potential and bulk density on the growth of Fusarium oxysporum f. sp. raphani. Soil Biol Biochem 28(9):1139-1145. doi:10.1016/0038-0717(96) 00134-4

Trail F (2009) For blighted waves of grain: Fusarium graminearum in the postgenomics era. Plant Physiol 149(1):103-110. doi:10.1104/ pp.108.129684

Trail F, Xu JR, San Miguel P, Halgren RG, Kistler HC (2003) Analysis of expressed sequence tags from Gibberella zeae (anamorph Fusarium graminearum). Fungal Genet Biol 38(2):187-197. doi:10.1016/s1087-1845(02)00529-7

Tschanz AT, Horst RK, Nelson PE (1976) Effect of environment on sexual reproduction of Gibberrella zeae. Mycologia 68(2):327340. doi:10.2307/3759003

Van den Brink J, de Vries RP (2011) Fungal enzyme sets for plant polysaccharide degradation. Appl Microbiol Biotechnol 91 (6):1477-1492. doi:10.1007/s00253-011-3473-2

Velluti A, Marin S, Bettucci L, Ramos AJ, Sanchis V (2000) The effect of fungal competition on colonization of maize grain by Fusarium moniliforme, $F$. proliferatum and $F$. graminearum and on fumonisin B-1 and zearalenone formation. Int J Food Microbiol 59(12):59-66. doi:10.1016/S0168-1605(00)00289-0

Vilain M (1989) Plant production volume 2. La production vegetale. Volume 2 - La maîtrise technique de la production. Lavoisier, Paris

Wanjiru WM, Kang ZS, Buchenauer H (2002) Importance of cell wall degrading enzymes produced by Fusarium graminearum during infection of wheat heads. Eur J Plant Pathol 108(8):803-810. doi:10.1023/A:1020847216155

Yi CL, Kaul HP, Kubler E, Aufhammer W (2002) Populations of Fusarium graminearum on crop residues as affected by incorporation depth, nitrogen and fungicide application. Z Pflanzenk Pflanzens J Plant Dis Prot 109(3):252-263

Yuen GY, Schoneweis SD (2007) Strategies for managing Fusarium head blight and deoxynivalenol accumulation in wheat. Int J Food Microbiol 119(1-2):126-130. doi:10.1016/ j.ijfoodmicro.2007.07.033 